\title{
Produksi Minyak Atsiri Untuk Mengembangkan Desa Pelutan, Kecamatan Gebang, Purworejo, Jawa Tengah Sebagai Sentra Minyak Atsiri
}

\author{
Noor Fitri ${ }^{1}$, Indah Safitri ${ }^{2}$, Krisna Merdekawati ${ }^{3}$ \\ ${ }^{1}$ Prodi Kimia, FMIPA UII \\ ${ }^{2}$ Prodi Akutansi, FE UII \\ ${ }^{3}$ Prodi Pendidikan Kimia, FMIPA UII \\ *Corresponding Email: noor.fitri@ uii.ac.id
}

\begin{abstract}
ABSTRAK
Purworejo menjadi salah satu sentra penghasil rempah-rempah di Jawa Tengah. Terdapat sekitar 75 pabrik jamu mengandalkan bahan baku dari Purworejo. Daerah penyumbang rempah-rempah terbanyak di Kabupaten Purworejo adalah Desa Pelutan. Rempah-rempah tersebut antara lain kapulaga, kemukus, temulawak, kencur, kunyit, jahe, serai wangi. Potensi tanaman tradisional rempah-rempah yang ada selama ini belum diarahkan dan dikembangkan menjadi suatu produk bernilai jual dan baru menjadi komoditas perdagangan bahan baku. Masyarakat belum memiliki kesadaran yang tinggi akan potensi yang ada di sekitar lingkungan mereka untuk dikelola sendiri menjadi produk bernilai jual yaitu minyak atsiri. Permasalahan tersebut diakibatkan dari tingkat kesadaran dan pengetahuan masyarakat dalam mengolah hasil pertanian tersebut sangat rendah, di samping itu tidak adanya penyuluh dan pendamping tentang pengembangan potensi pertanian yang ada. Berdasarkan permasalahan tersebut maka masyarakat perlu diberdayakan supaya dapat mengolah potensi yang ada menuju peningkatan ekonomi warga. Model pemberdayaan yang digunakan adalah metode partisipatif Participatory Rural Apraisal (PRA). Pertimbangan dipilihnya metode ini adalah bahwa yang menghadapi masalah adalah mitra, oleh karena itu keterlibatan mitra dalam penentuan pemecahan masalah yang dihadapi dan penyelesaiannya sangat diperlukan. Solusi yang diterapkan dalam mengatasi permasalahan tersebut yaitu dengan cara: 1). pendampingan cara pemilihan dan pemanfaatan bahan baku, 2). pengolahan bahan baku menjadi produk minyak atsiri dan 3). pendampingan pemasaran minyak atsiri, 4). pengadaan teknologi tepat guna. Kegiatan pemberdayaan yang dilaksanakan mendapat dukungan penuh dari Pemerintah dan masyarakat Desa Pelutan. Pengolahan potensi desa berupa rempah-rempah menjadi produk berbasis minyak atsiri, dapat menjadikan Desa Pelutan sebagai sentra industri berbasis minyak atsiri dan meningkatkan perekonomian masyarakat.
\end{abstract}

Kata Kunci: minyak atsiri, Desa Pelutan, Purworejo

\begin{abstract}
Purworejo became one of the centers producing spices in Central Java. There are about 75 herbal medicine factories that rely on raw materials from Purworejo. The biggest contributor to spices in Purworejo Regency is Pelutan Village. Spices include cardamom, kemukus, ginger, kencur, turmeric, ginger, and lemon grass. The potential of existing traditional spices has not been directed and developed into a value product and has only become a commodity of raw material trading. The
\end{abstract}


JAMALI - Volume. 01, Issue. 02, September 2019

community does not yet have a high awareness of the potential that exists around their environment to be managed themselves into a product such as essential oils. The problem is low awareness and knowledge of the community in processing agricultural, in addition there are no instructors and assistants about the development of existing agricultural potential. Based on these problems, the community needs to be empowered in order to be able to cultivate the existing potential towards improving the people's economy. The empowerment model used is the participatory Rural Appraisal (PRA) method. The solution in overcoming these problems is by: 1). assistance in how to choose and use raw materials, 2). processing raw materials into essential oil products and 3). marketing assistance for essential oils, 4). procurement of appropriate technology. The empowerment activities carried out received full support from the Government and the community of Pelutan Village. Processing the village's potential in the form of spices into essential oil-based products, can make Pelutan Village a center for essential oil-based industries and improve the community's economy.

Keywords: lemongrass, essential oil, Pelutan Village.

\section{PENDAHULUAN}

Desa Pelutan adalah sebuah desa yang terletak di Kabupaten Purworejo. Seperti kebanyakan wilayah di Purworejo, aktivitas ekonomi pada Desa Pelutan bergantung pada sektor pertanian. Secara demografi wilayah Desa Pelutan masuk dalam wilayah Kecamatan Gebang, mempunyai jarak 10 km dari pusat Kabupaten. Desa Pelutan terdiri dari 3 dusun dengan luas 285,2 Ha. Struktur organisasi dan tata kerja pemerintahan di Desa Pelutan terdiri dari Kepala Desa (Kades), Sekretaris Desa (Sekdes), Kepala Urusan (terdiri dari 5 orang), dan Kepala Dusun. Desa Pelutan mempunyai jumlah penduduk 917 orang yang terdiri dari 475 orang laki-laki dan 442 orang perempuan, dengan jumlah Rumah Tangga Miskin (RTM) berjumlah 83 RTM [1].

Di tingkat provinsi, Purworejo menjadi salah satu sentra penghasil rempah-rempah (bahasa jawa: empon-empon), antara lain kapulaga, kemukus, temulawak, kencur, kunyit, serai wangi dan jahe. Selain untuk bumbu penyedap masakan juga untuk bahan baku jamu. Sekitar 75 pabrik jamu di Jawa Tengah mengandalkan bahan baku dari Purworejo [2]. Daerah penyumbang rempah-rempah terbanyak di Kabupaten Purworejo adalah Desa Pelutan. Potensi tanaman empon-empon di Desa Pelutan dapat dilihat pada Tabel 1.

(Tabel 1. Potensi dan sebaran empon-empon Desa Pelutan)

\begin{tabular}{|c|c|}
\hline $\begin{array}{c}\text { Jenis } \\
\text { Tanaman }\end{array}$ & $\begin{array}{c}\text { Lokasi Dusun } \\
\text { Penghasil }\end{array}$ \\
\hline Jahe & Krajan \\
\hline Temulawak & Krajan \\
\hline Kencur & Tegalsari \\
\hline Kunyit & Pasuruhan \\
\hline
\end{tabular}


Fitri $^{1}$, Safitri $^{2}$, Merdekawati $^{3}$

\begin{tabular}{|c|c|}
\hline Kapulaga & Tegalsari \\
\hline Kemukus & Krajan \\
\hline Serah wangi & Pasuruhan \\
\hline
\end{tabular}

Empon-empon yang dihasilkan masyarakat Desa Pelutan, masih terbatas pemanfaatannya. Selain dijual kepada pengepul, empon-empon baru dimanfaatkan sebagai bumbu dapur, belum ditingkatkan menjadi usaha skala desa. Masyarakat Pelutan belum memiliki kesadaran yang tinggi akan potensi yang dimiliki. Kesadaran masyarakat akan pentingnya berwirausaha masih rendah, bertolak belakang dengan sumber daya alam yang melimpah. Empon-empon dapat diolah untuk meningkatkan harga jual, salah satunya dengan pembuatan produk berbasis minyak atsiri.

Dari hasil survai dan observasi di lapangan, ditemui beberapa permasalahan untuk mengembangkan potensi empon-empon. Permasalahan tersebut antara lain belum adanya kesadaran yang tinggi akan potensi yang ada di Desa Pelutan. Potensi empon-empon yang ada selama ini belum diarahkan dan dikembangkan menjadi suatu produk minyak atsiri. Selain itu masyarakat Desa Pelutan belum memiliki pengetahuan mengenai cara produksi yang terstandarisasi, seperti pemilihan dan pemanfaatan bahan baku, pengolahan bahan baku, hingga pemrosesan menjadi produk yang bernilai jual. Alat-alat atau fasilitas pendukung untuk pengembangan pengolahan bahan baku untuk produk juga masih sederhana sehingga diperlukan suatu alat pendukung yang lebih modern sehingga mampu meningkatkan kualitas dan efektifitas waktu. Dari aspek pasca produksi, masyarakat juga masih belum memiliki kemampuan dalam mengemas produk dengan baik dan membuat kemasan yang memenuhi standar. Ketersedian alat pengemasan juga kurang memadai. Selain itu, masyarakat kurang mengetahui bagaimana cara pemasaran produk yang baik sehingga produk yang dihasilkan akan terus berlanjut dan berkembang.

Berdasarkan permasalahan tersebut maka masyarakat Desa Pelutan perlu diberdayakan supaya dapat mengolah potensi yang ada menuju peningkatan ekonomi warga. Solusi yang di terapkan dalam mengatasi permasalahan tersebut yaitu dengan cara: 1) pendampingan cara pemilihan dan pemanfaatan bahan baku, 2) pengolahan bahan baku menjadi produk minyak atsiri, 3) pendampingan pemasaran minyak atsiri, 4) pengadaan teknologi tepat guna.

Tanaman serai merupakan tanaman tahunan yang tumbuh pada daerah yang tidak tetap atau hidup meliar, hidup lama, dan kuat. Tanaman ini biasanya mempunyai tinggi berkisar antara 40-70 $\mathrm{cm}$, mempunyai daun berwarna hijau muda, batang tumbuhan tidak berkayu, dan tersusun atas epidermis batang, jaringan pengangkut, jaringan korteks, dan empulur batang. Pada jaringan parenkim korteks terdapat sel atau kelenjar minyak, sehingga tumbuhan ini dapat digunakan untuk membuat minyak atsiri [3-4]. Tanaman ini banyak terdapat di Desa Pelutan akan tetapi belum dimanfaatkan untuk dijadikan minyak serai dapur. Desa Pelutan itu sendiri memiliki berbagai macam 
JAMALI - Volume. 01, Issue. 02, September 2019

rempah-rempah yang dapat diolah menjadi produk dengan nilai ekonomis yang tinggi sehingga dapat meningkatkan perekonomian Desa Pelutan.

Serai dapur (Cymbopogon citratus) adalah salah satu tanaman penghasil minyak atsiri. Di Indonesia, spesies yang lebih dikenal adalah West Indian Lemongrass dan masyarakat umumnya menggunakannya sebagai campuran bumbu dapur dan rempah-rempah karena mempunyai aroma khas seperti lemon. Aroma ini diperoleh dari senyawa sitral yang terkandung dalam minyak atsiri serai [5]. Minyak atsiri sereh dapur dan sereh wangi memiliki khasiat sebagai antijamur dan antibakteri [6-7].

Minyak atsiri merupakan salah satu jenis minyak volatil yang multimanfaat. Karakteristik fisiknya berupa cairan kental yang dapat disimpan pada suhu ruang. Bahan baku miyak ini diperoleh dari berbagai bagian tanaman seperti daun, bunga, buah, biji, kulit biji, batang, akar atau rimpang. Salah satu ciri utama minyak atsiri yaitu mudah menguap dan beraroma khas. Oleh karena itu, minyak ini banyak digunakan sebagai bahan dasar pembuatan wewangian dan kosmetika. Selain itu minyak atsiri juga digunakan sebagai flavor dalam bumbu masak [4,8].

Minyak atsiri dari tanaman serai dapur dalam perdagangan dikenal dengan nama Lemongrass Oil. Kandungan utama minyak serai dapur adalah sitral dan juga mengandung sitronelal, metilheptan, n-desil aldehida, linalool, geraniol [9]. Minyak serai dapur merupakan salah satu jenis minyak atsiri terpenting. Minyak atsiri ini digunakan untuk menghasilkan sitral yang merupakan konstituen utama dari minyak serai dapur. Sitral merupakan bahan pembuat ionon. Minyak serai dapur memiliki bau lemon yang keras karena mengandung kadar sitral yang tinggi (75\% sampai 85\%) sehingga minyak serai dapur dinamakan lemongrass oil. Minyak serai dapur dapat digunakan sebagai bahan baku dalam industri kosmetik, sabun[9,10].

Produksi minyak atsiri dari tanaman serai dapur dapat dilakukan dengan metode distilasi air dan uap. Menurut Yulianti dan Suyanti (2012), metode penyulingan dengan air dan uap disebut dengan sistem kukus atau sistem uap tak langsung [11]. Prinsip kerja penyulingan ini adalah sebagai berikut : ketel penyulingan diisi air sampai pada batas saringan. Bahan baku diletakkan di atas saringan, sehingga tidak berhubungan langsung dengan air yang mendidih, tetapi akan berhubungan dengan uap air. Oleh karena itu cara penyulingan semacam ini disebut penyulingan tidak langsung (indirect distilation). Air yang menguap akan membawa partikel partikel minyak atsiri dan dialirkan melalui pipa ke alat pendingin, sehingga terjadi pengembunan dan uap air yang bercampur minyak atsiri tersebut akan mencair kembali. Selanjutnya dialirkan ke alat pemisah untuk memisahkan minyak atsiri dari air [12].

\section{METODE PELAKSANAAN}

Metode pelaksanaan pemberdayaan ini merupakan kolaborasi dari tiga pihak. Pihak pertama adalah Universitas Islam Indonesia sebagai pemrakarsa dan pelaksana program, pihak kedua adalah 
DRPM Dikti yang berperan sebagai penyandang dana; dan pihak ketiga adalah Pemerintah Desa Pelutan sebagai pemilik otoritas wilayah.

Model pemberdayaan yang digunakan adalah metode partisipatif Participatory Rural Apraisal (PRA). Pertimbangan dipilihnya metode ini adalah bahwa yang menghadapi masalah adalah mitra, oleh karena itu keterlibatan mitra dalam penentuan pemecahan masalah yang dihadapi dan penyelesaiannya sangat diperlukan. Berikut strategi penyelesain masalah yang dilaksanakan selama program:

1. Melakukan pendampingan dan penyuluhan kepada masyarakat desa mengenai pentingnya pemanfaatan tanaman rempah-rempah/empon-empon menjadi suatu produk minyak atsiri.

2. Melaksanakan perencanaan kegiatan bisnis (bisnis plan) di tingkat kelompok masyarakat sasaran.

3. Melaksanakan Pelatihan teknologi pengolahan tanaman tradisional menjadi produk minyak atsiri

4. Melaksanakan penyediaan alat-alat pendukung usaha yang dapat meningkatkan kualitas produk atsiri

5. Melakukan pelatihan mendesain kemasan yang menarik dan efisien

6. Melakukan pelatihan pemasaran berbasis online

7. Melakukan pelatihan manajemen usaha dan administrasi keuangan.

\section{HASIL DAN PEMBAHASAN}

\section{Pendampingan dan penyuluhan kepada masyarakat desa mengenai pentingnya pemanfaatan tanaman rempah-rempah menjadi produk minyak atsiri.}

Pendampingan dan penyuluhan kepada masyarakat desa mengenai pentingnya pemanfaatan tanaman rempah-rempah menjadi produk minyak atsiri dilakukan pada tanggal 24 Juli 2019. Penyuluhan ini bertujuan agar masyarakat dan perangkat Desa Pelutan memahami bahwa Desa Pelutan memiliki potensi rempah-rempah yang digunakan sebagai bahan baku untuk pembuatan minyak atsiri. Upaya pengembangan pertanian rempah-rempah dapat diperluas, sehingga Desa Pelutan dapat berkembang sebagai sentra produksi minyak atsiri.

Dalam program sosialisasi dijelaskan langkah-langkah kerja yang akan dilakukan. Langkah pertama dalam progam ini adalah survei lokasi awal yang tujuannya adalah mengetahui permasalahan dan potensi yang ada di Desa Pelutan. Setelah permasalahan dan potensi tersebut benar-benar dapat dimanfaatkan, langkah selanjutnya adalah melakukan koordinasi dengan mitra. Dalam koordinasi ini telah dicapai kesepakatan untuk melaksanakan kegiatan sesuai dengan proses maupun waktu pelaksanaannya. Kesepakatan ini menjadi komitmen penting untuk suksesnya program pemberdayaan.

Sebagai mitra, dalam kesepakatan awal, Pemerintah Desa Pelutan siap bekerjasama dalam pengembangan produk pengolahan tanaman tradisional hasil panen yang berupa rempah-rempah 
JAMALI - Volume. 01, Issue. 02, September 2019

menjadi produk minyak atsiri. Selama program berjalan Pemerintah Desa Pelutan membantu jalannya program dengan bentuk dana in cash sebesar Rp5 juta. dalam bentuk bantuan konsumsi, snack pertemuan dan pelatihan serta dana in kind dalam bentuk pemberian fasilitas, peralatan, ruang pertemuan, sound sistem, alat kerja administrasi dan listrik.

Program pemberdayaan yang dilakukan, melibatkan mahasiswa yang bergabung dalam KKN PPM. Sebanyak 30 mahasiswa lintas displin ilmu dilibatkan. Kegiatan diawali dengan rekruitmen dan pembekalan mahasiswa. Mahasiswa yang terlibat antara lain dari Prodi Kimia, Farmasi, Kedokteran, Akuntansi, Manajemen, Teknik Industri, Teknik Mesin. Pembekalan mahasiswa berkaitan dengan tema pengolahan empon-empon menjadi produk berbasis minyak atsiri.

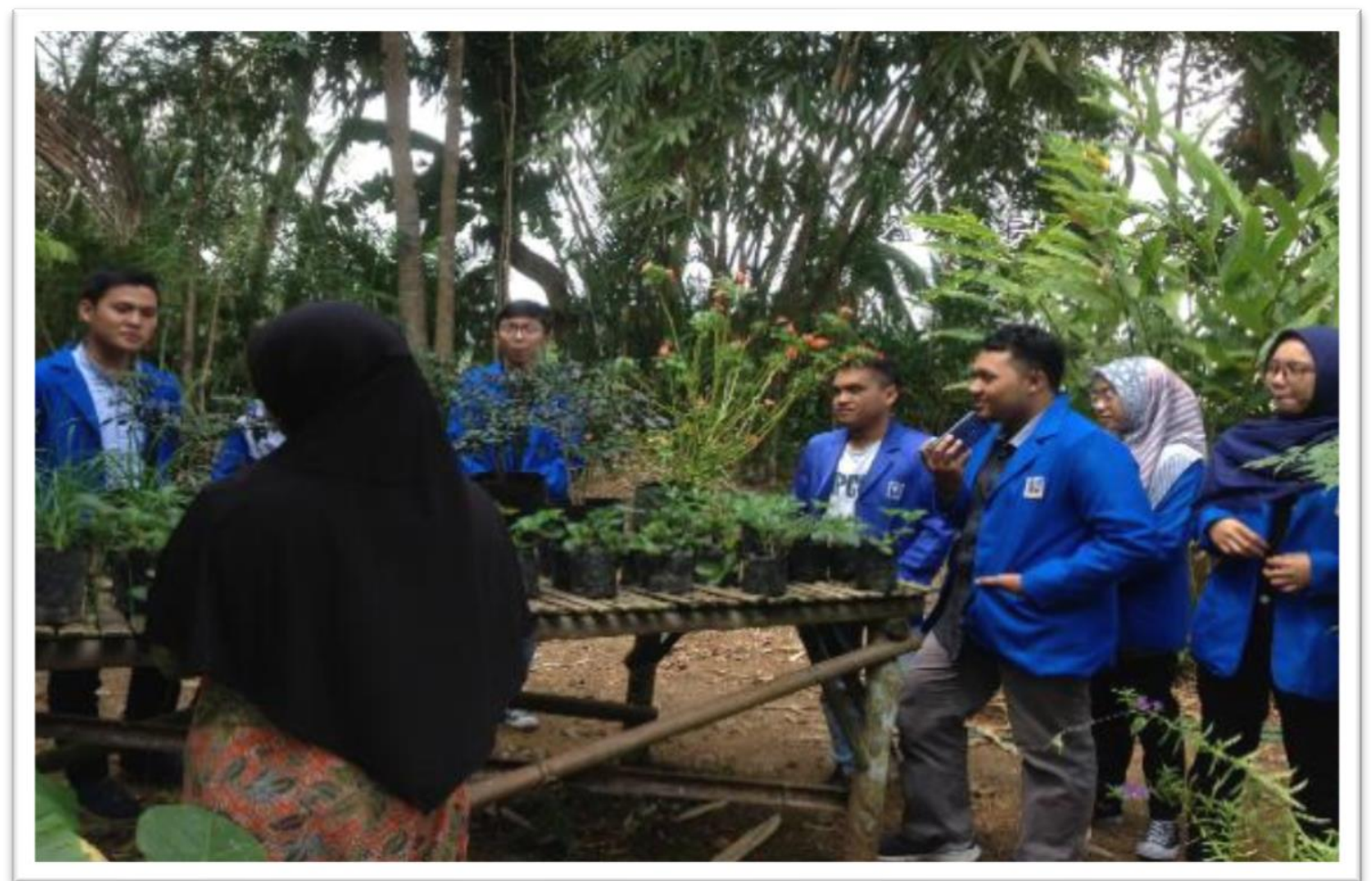

(Gambar 1. Pendampingan dan penyuluhan kepada masyarakat desa mengenai pentingnya pemanfaatan tanaman rempah-rempah menjadi produk minyak atsiri)

\section{Pelatihan kegiatan bisnis (bisnis plan) di tingkat kelompok masyarakat sasaran.}

Pelatihan bisnis plan yang dilaksanakan oleh mahasiswa jurusan ekonomi kepada warga desa pelutan bertujuan untuk memudahkan masyarakat desa pelutan untuk memulai usaha dan membantu masyarakat untuk tetap kreatif dan fokus pada tujuan yang telah ditetapkan saat awal ingin menjalankan sebuah bisnis.

Dalam penjelasannya mahasiswa membantu warga untuk menganalisis SWOT mengenai bisnis minyak atsiri, didaptakan kesimpulan, bahwa kelebihan yang dimiliki oleh Desa Pelutan adalah bahanbaku yang mudah didapatkan di Desa Pelutan, dan di Indonesia sendiri menjadi produsen minyak serai terbesar nomer dua didunia. Kelemahannya dalam menjalankan bisnis minyak atsiri 
apabila dalam penyulingannya menggunakan gas, biaya produksi relative mahal, dan peralatan yang dimiliki desa masih sederhana sehingga hasilnya tidak maksimal, namun dibalik kekurangannya bisnis ini sangat berpotensi, karena memiliki peluang yang besar yang pertama kondisi tanah didesa Pelutan sangat subur sehingga memudahkan masyarakat untuk membudidayakan taman serai untuk memproduksi minyak atsiri serai, serta sudah memiliki pasarnya sendiri dan masih banyak dibutuhkan di pasaran. Namun dibalik peluang yang ada ancaman yang akan dihadapi adalah banyaknya pesaing-pesaing besar serata kualitas minyak akan dipasarkan harus lebih baik dari kualitas minyak-minyak atsiri yang berkembang dipasaran.

\section{Pelatihan teknologi pengolahan tanaman tradisional menjadi produk minyak atsiri}

Proses produksi minyak atsiri serai dapur dilaksanakan menggunakan metode destilasi. Destilasi adalah suatu metode pemisahan campuran yang didasarkan pada perbedaan tingkat volalitas (kemudahan suatu zat untuk menguap) pada suhu dan tekanan tertentu. Destilasi merupakan proses fisika dan tidak terjadi adanya reaksi kimia selama proses berlangsung. Dasar utama pemisahan dengan cara destilasi adalah perbedaan titik didih cairan pada tekanan tertentu. Proses destilasi biasanya melibatkan suatu penguapan campuran dan diikuti dengan proses pendinginan dan pengembunan. Minyak-minyak atsiri alami yang mudah menguap dapat dipisahkan melalui destilasi. Banyak sekali minyak atsiri alami yang dapat diperoleh dengan cara destilasi, salahsatunya adalah minyak serai. Penyulingan minyak serai dapat diperoleh dengan destilasi kukus atau uap-air.

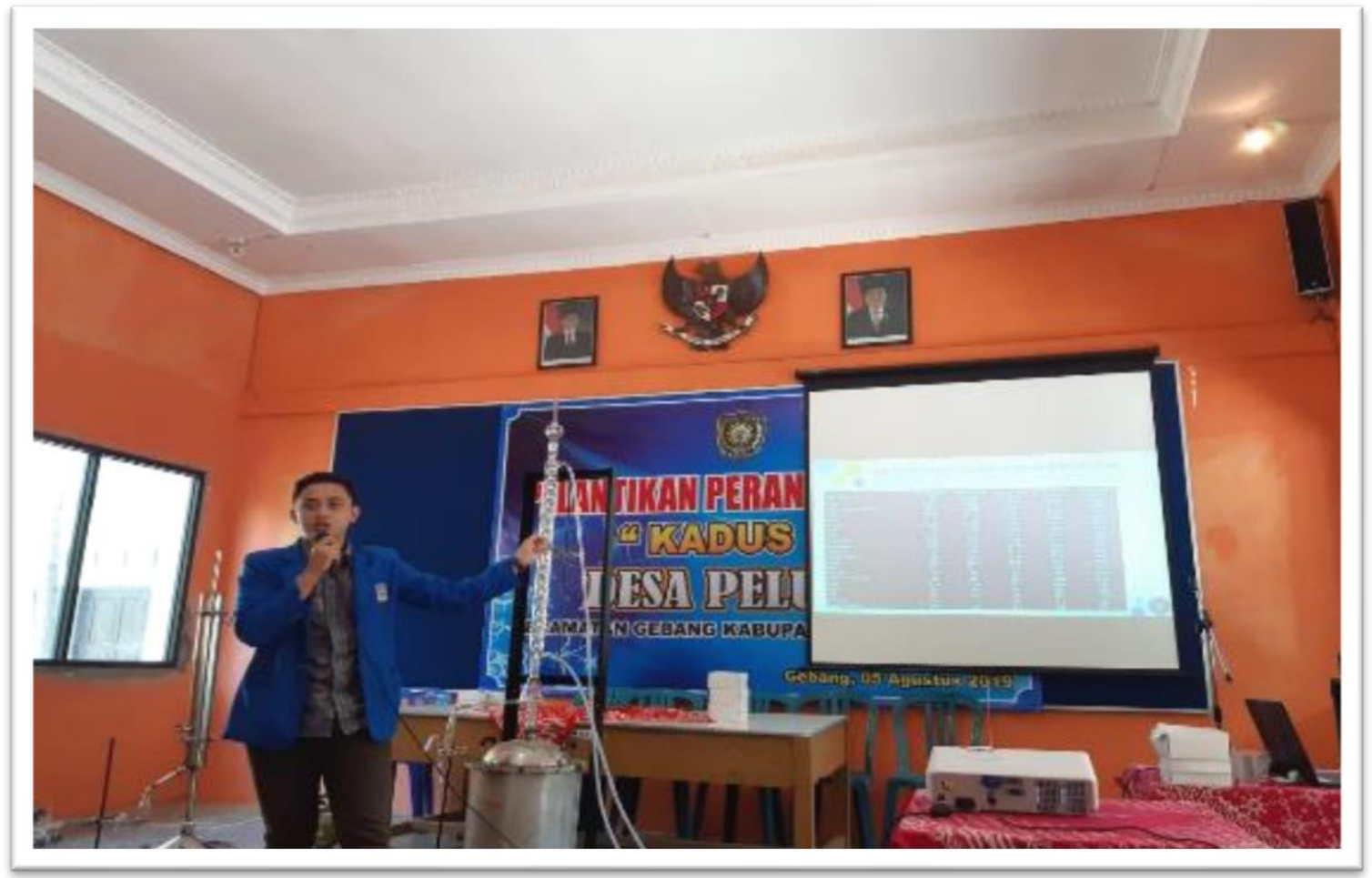




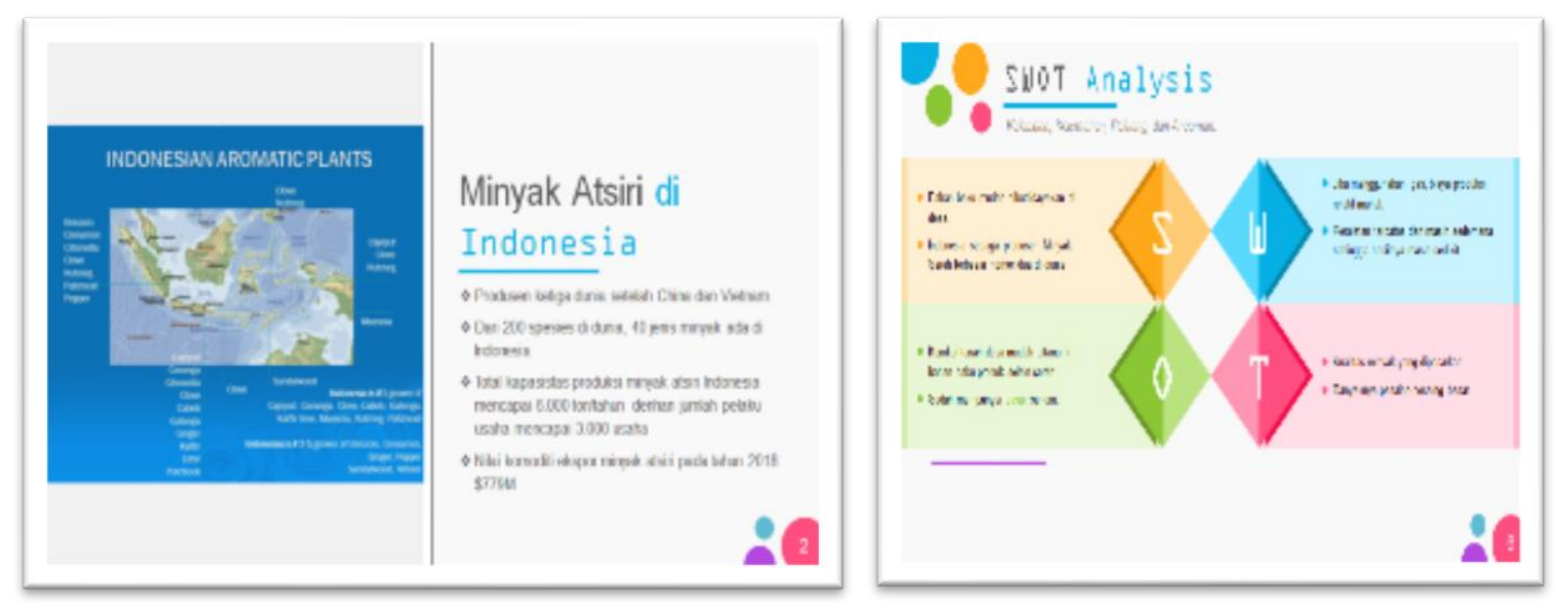

(Gambar 2. Pelatihan Bisnis Plan di Masyarakat tentang Produksi Minyak Atsiri)

Destilasi kukus atau uap-air adalah penyulingan dimana bahan baku dan air tidak bersinggungan langsung karena dibatasi dengan saringan diatas air. Metode kukus ini biasa dilengkapi sistem kohobasi yaitu air kondensat yang keluar dari separator masuk kembali secara otomatis ke dalam ketel agar meminimalkan kehilangan air. Adapun skema alat destilasi kukus dapat dilihat pada Gambar 3.

Ketika akan dilakukan destilasi, daun serai yang akan digunakan dipotong menjadi kecil-kecil agar minyak yang didapat lebih mudah keluar melalui batas-batas pembelahannya dan untuk memudahkan ketika akan dimasukkan ke dalam ketel. Daun yang telah dipotong-potong tersebut kemudian ditimbang sebanyak $3 \mathrm{~kg}$ dan dimasukkan ke dalam ketel yang telah berisi air sebatas angsang, lalu ketel ditutup dengan rapat. Adapun kegunaan pengisisan air tersebut dalam ketel pembangkit uap adalah pada saat pemanasan air tersebut menguap dan uapnya tersebut melewati kondensasi. Adapun pemanasan dimaksudkan untuk menguapkan komponen-komponen yang lebih mudah menguap dan kemudian uap yang diperoleh dikondensasikan kembali menjadi cair dengan bantuan air pendingin. Suhu sampai ketel pembangkit uap mendidih $29,5^{\circ} \mathrm{C}$ sampai $80,3^{\circ} \mathrm{C}$, dalam waktu kurang lebih 3 jam. Setelah penguapan dan pengkondensasian minyak atsiri ditampung didalam separator bersama dengan air suling atau hidrosol. Setelah itu minyak dan hidrosol dipisahkan kemudian minyak ditampung dalam gelas. Minyak yang dihasilkan belum murni sehingga perlu ditambahkan Natrium Sulfat untuk memurnikannya. Minyak atsiri serai dapur yang telah murni diletakkan dalam wadah dan ditutup rapat. 


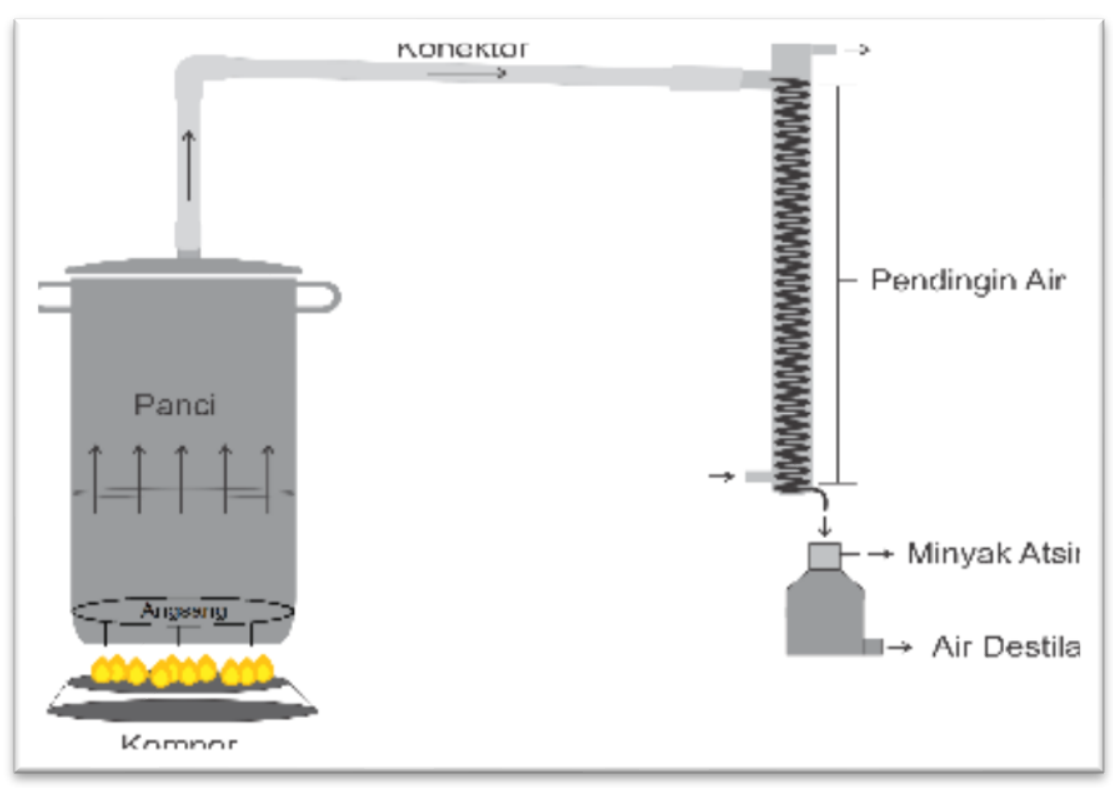

(Gambar 3. Skema Alat Distilasi Kukus)

Proses produksi menghasilkan minyak serai dapur sebanyak $10 \mathrm{~mL}$ dari bahan baku sebanyak $3 \mathrm{~kg}$. Minyak serai yang dihasilkan memiliki warna kuning keemasan dan memiliki aroma khas serai. Presentasi rendemen minyak atsiri serai yang diperoleh sebesar 0,33\%.

Pelatihan dan praktek penyulingan minyak atsiri dari serai dilaksanakan dibalai desa. Kegiatan ini dihadirin oleh warga desa pelutan dan perakat desa pelutan. Warga desa pelutan sangat antusias dalam pelaksaan praktek pembuatan minyak atsiri dari daun serai. Warga langsung ikut dalam perancangan alat penyulingan minyak dan produksi minyak atsiri. Warga masyarakat berharap besar semoga dengan adanya pelatihan ini membuka wawasan serta memotivasi warga pelutan untuk berwirausaha dengan pengembangan produk minyak atsiri dari serai.

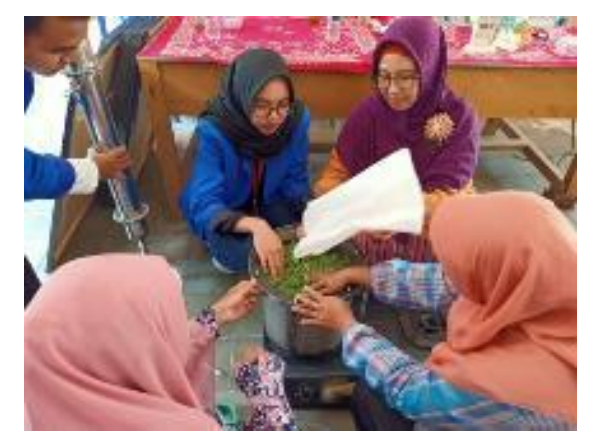

(Gambar 4. Pelatihan dan Praktek Pembuatan Minyak Atsiri dari Serai)

\section{Melaksanakan penyediaan alat-alat pendukung usaha yang dapat meningkatkan kualitas produk atsiri}

Dalam acara koordinasi desa mengenai pengembangan minyak atsiri, Ibu Dr. Noor Fitri, S.Si, M.Si sebagai ketua Tim Hibah KKN PPM dan Dosen Pendamping Lapangan 1 (DPL1 ), menyampaikan 
JAMALI - Volume. 01, Issue. 02, September 2019

mengenai program unggulan pengembangan minyak atsiri bagi masyarakat Desa Pelutan. Dalam pengembangan program unggulan minyak atsiri, warga masyarakat akan dilatih langsung cara pembuatannya minyak atsiri, sekaligus penyuluhan kewirausahaan, mengenai bisnis plan, manajemen keuangan, hingga pemasaran dan pengemasan minyak atsiri. Kemudian dilanjutkan dengan serah terima alat-alat penyulingan minyak atsiri secara simbolis. Bapak kepala desa sangat antusias dengan program hibah KKN-PPM, karena hal tersebut sangat bermanfaat untuk memberi wawasan serta inovasi pada masyarakat desa Pelutan. Bapak Kepala Desa berharap mudah-mudahan dengan adanya program unggulan minyak atsiri ini mampu meningkatkan perekonomian masyarakat desa pelutan dan menjadi contoh untuk desa-desa lain.
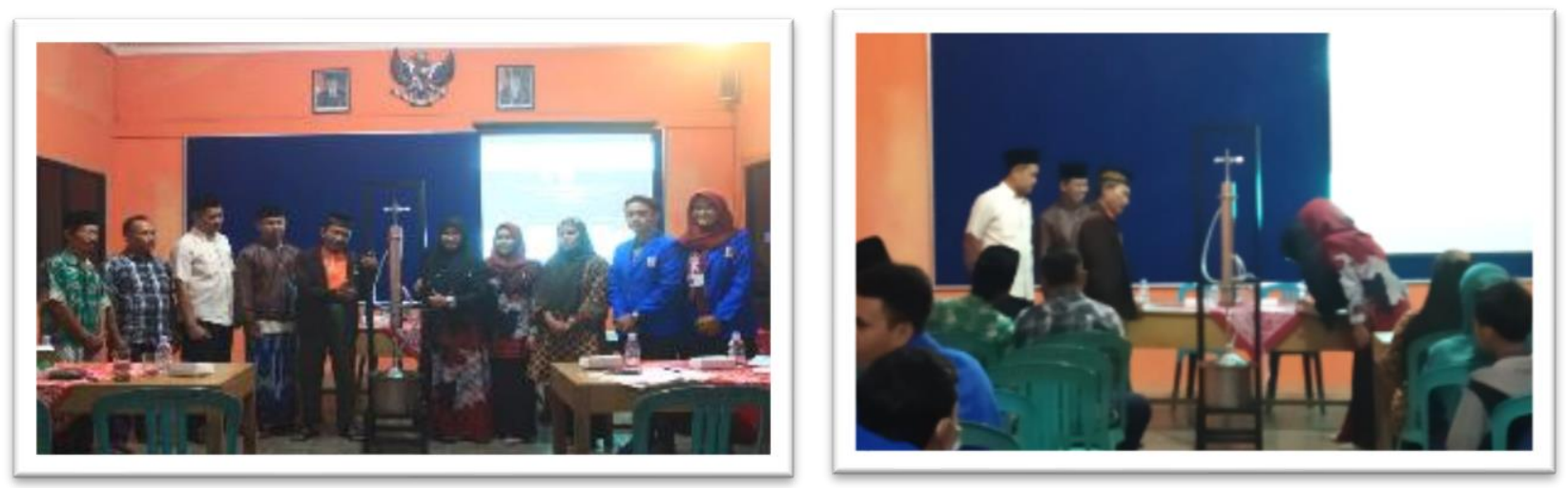

(Gambar 5. Serah Terima Alat Distilasi Minyak Atsiri)

\section{Pelatihan mendesain kemasan yang menarik dan efisien}

Secara umum kemasan adalah bagian terluar yang membungkus suatu produk dengan tujuan untuk melindungi produk dari cuaca, guncangan, dan benturan-benturan terhadap benda lain. Selain itu packaging dalam suatu produk bertujuan untuk menampilkan image dan pandangan terhadap isi dari produk tersebut. Pengemasan produk minyak atsiri harus didesain sebaik mungkin untuk menciptakan suatu image bahwa produk minyak atsiri dari serai ini berasal dari Desa Pelutan. Pembuatan merek haruslah menarik dan mudah diingat diingat oleh konsumen, untuk contoh desain kemasan produk minyak atsiri pelutan untuk sementara yaitu sebagai berikut.
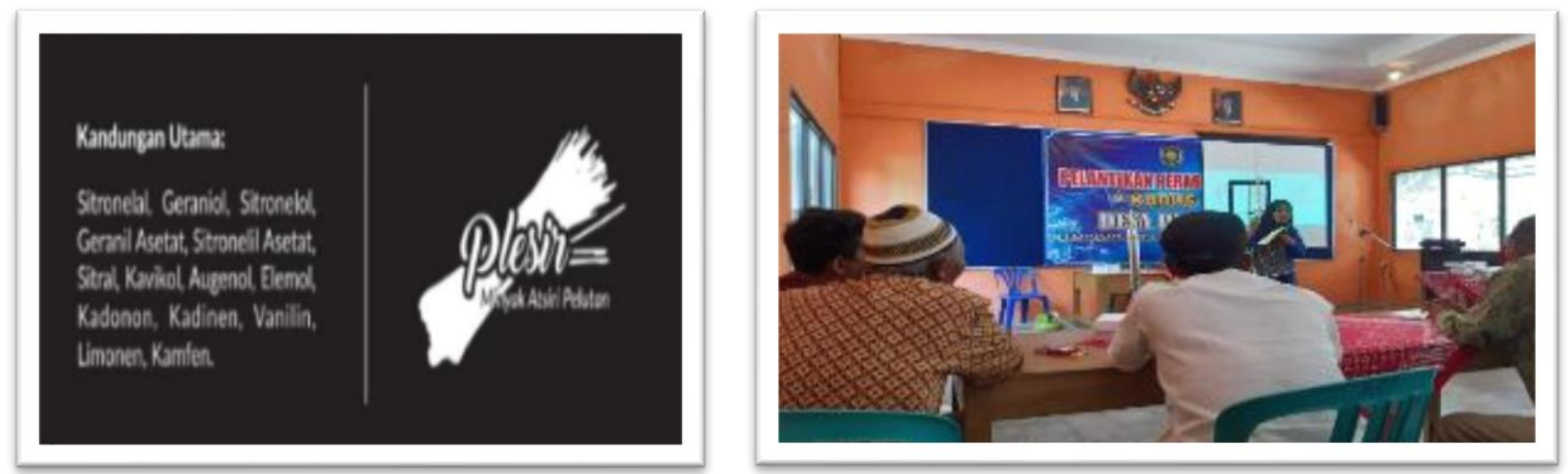

(Gambar 6. Pendampingan Desain dan Pengemasan Produk) 


\section{Pelatihan pemasaran berbasis online}

Di era digital saat ini pentingnya para pelaku bisnis mengetahui pemasaran secara online, karena dengan pemasaran secara online pelaku usaha dapat memasarkan barangnya dengan jaringan yang lebih luas. Namun melihat kondisi lapangan didesa tidak semua masyarakat desa miliki media seperti laptop dan smartphone untuk melakukan pemasaran online, sehingga target sasaran dalam pelatihan pemdampingan pemasaran berbasis online minyak atsiri akan difokus untuk karang taruna, dan beberapa warga masyarakat yang memiliki media untuk melakukan pemasaran online. Namun dalam ini mahasiswa tetap memberikan wawasan dan pemahaman kepada masyarakat desa Pelutan secara umum pentingnya kita mengetahui pemasaran online, karena dengan pemasaran online kita dapat memangkas biaya untuk penyewaan toko, dan dapat memasarkan produk kita dengan jangkuan yang lebih luas.

Jika pengolahan minyak atsiri ini nantinya dapat berjalan, produk olahan hasil minyak atsiri nantinya dapat dipasarkan langsung melalui bukalapak, tokopedia, lazada, shopee, dan intagram bisnis argo yang langsung siap memasarkan produk dari produsen kepada konsumen yang membutuhkan, dan UII sebagai mitra kerjasama dalam KKN PPM siap membeli hasil produk minyak atsiri serai Desa Pelutan dan akan dipasarkan di ZAKEA. Jadi masyarakat tidak perlu khawatir jika nanti usaha pengolahan tanaman tradisional minyak atsiri ini berjalan dan mampu memproduksi minyak atsiri, karena dipasaran masih banyak yang membutuhkan sebagai campuran bahanbaku kosmetik atau parfum.
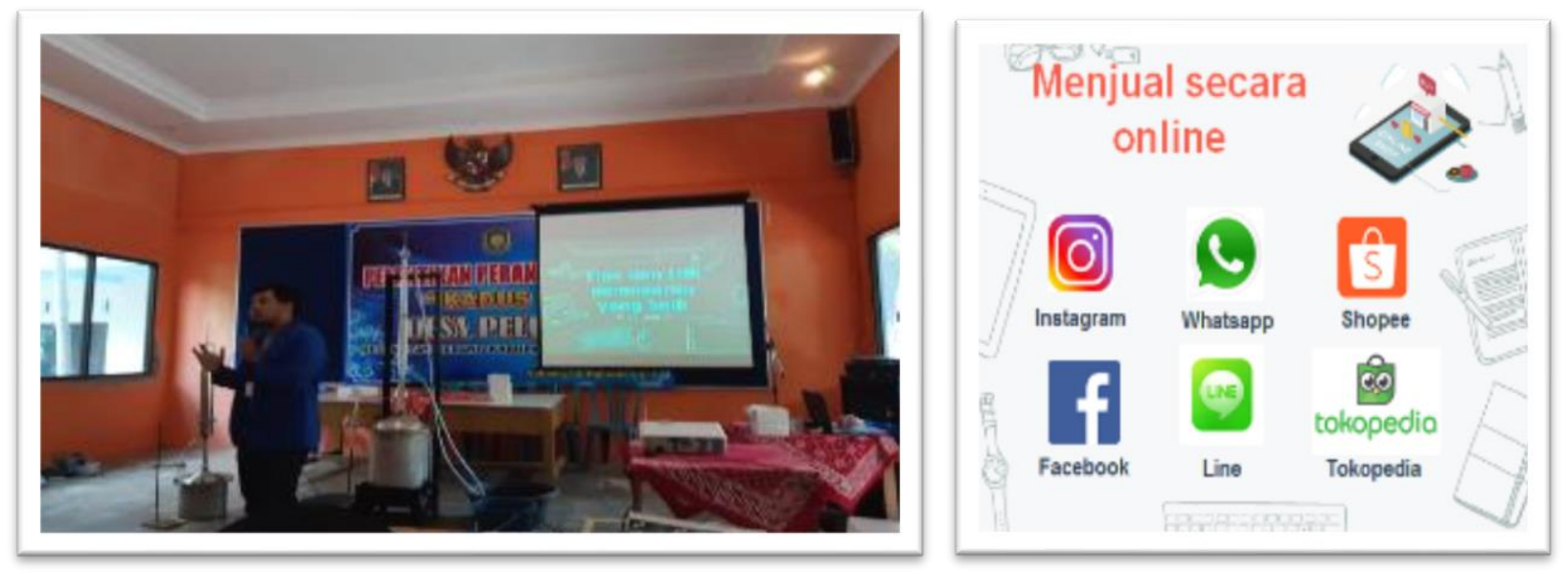

(Gambar 7. Pendampingan Pemasaran Minyak Atsiri Berbasis Online)

\section{Pelatihan manajemen usaha dan administrasi keuangan}

Pelatihan manajemen keuangan sangatlah penting diketahui oleh masyarakat desa Pelutan jika ingin menjalankan suatu bisnis, agar kita mengetahui apakah bisnis yang akan kita jalankan memberikan keuntungan atau sebaliknya mengalami kerugian. Dalam hal ini mahasiswa menjelaskan cara penulisan keuangan secara sederhana hingga pada keuntungan yang akan didapat setiap bulannya dalam pengolahan produk minyak atsiri. 
(Tabel 2. Perhitungan Produksi Minyak Atsiri)

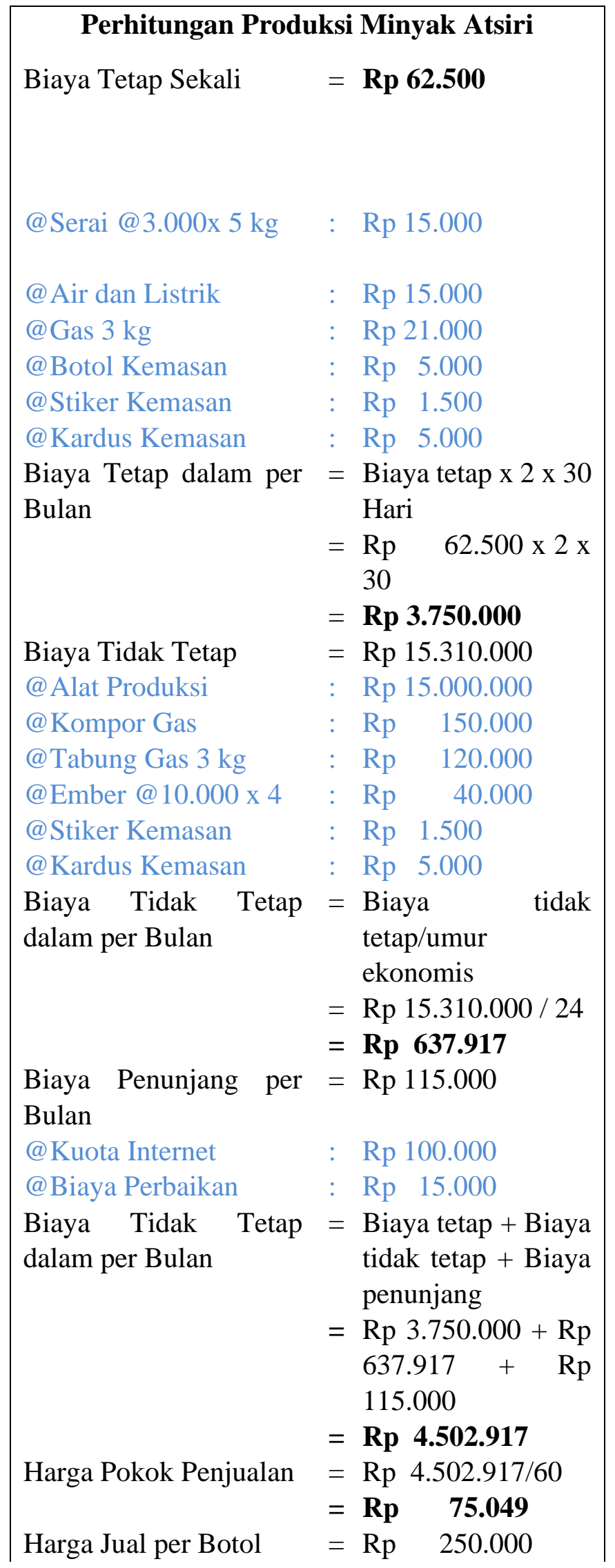

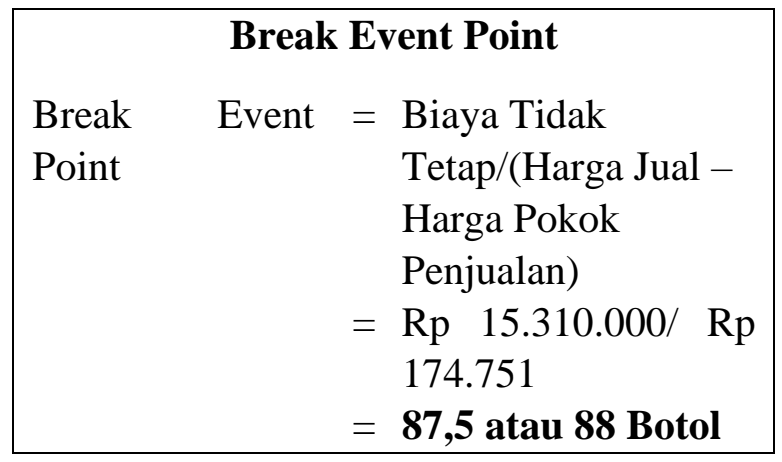




$\begin{aligned} \text { Keuntungan }= & \text { Harga Jual per } \\ & \text { Botol }- \text { Harga } \\ & \text { Pokok Penjualan } \\ = & \text { Rp 250.000 }- \text { Rp } \\ & 75.000 \\ = & \text { Rp 174.751 per } \\ & \text { Botol }\end{aligned}$

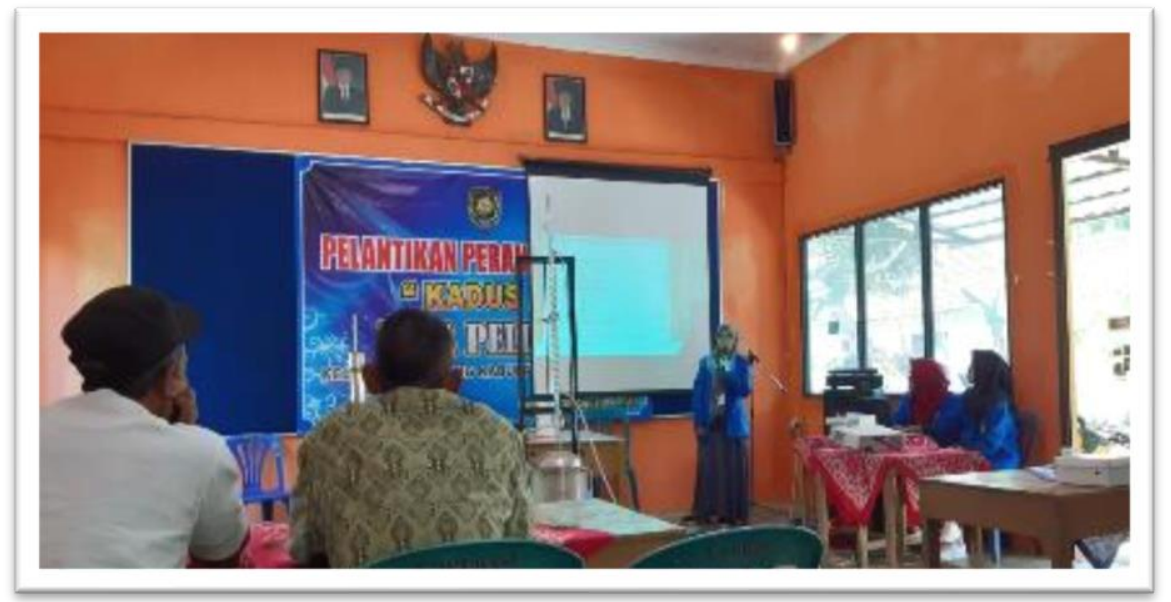

(Gambar 8. Pelatihan Manajemen Keuangan)

\section{Pengujian kualitas Produk Minyak atsiri desa Pelutan}

Pengujian kualitas produk minyak atsiri perlu dilakukan sebelum produk di pasarkan. Pengujian komposisi kimia minyak atsiri sereh dapur dilakukan di Laboratorium Terpadu UII. Gambar 9 dan Gambar 10., memperlihatkan kromatogram minyak sereh dapur. Berdasarkan hasil pengujian tersebut, diketahui bahwa kualitas minyak sereh dapur desa Pelutan, memenuhi syarat standar SNI. Pada Tabel 3 dan Tabel 4, ditampilkan komposisi kimiawi minyak sereh dapur yang berasal dari Batang (Tabel 3) serta minyak sereh dapur yang berasal daun dan batang. Kandungan citral pada minyak sereh dapur batang lebih tinggi $(54,57 \%)$ dibandingkan pada minyak sereh dapur yang berasal dari daun dan batang.

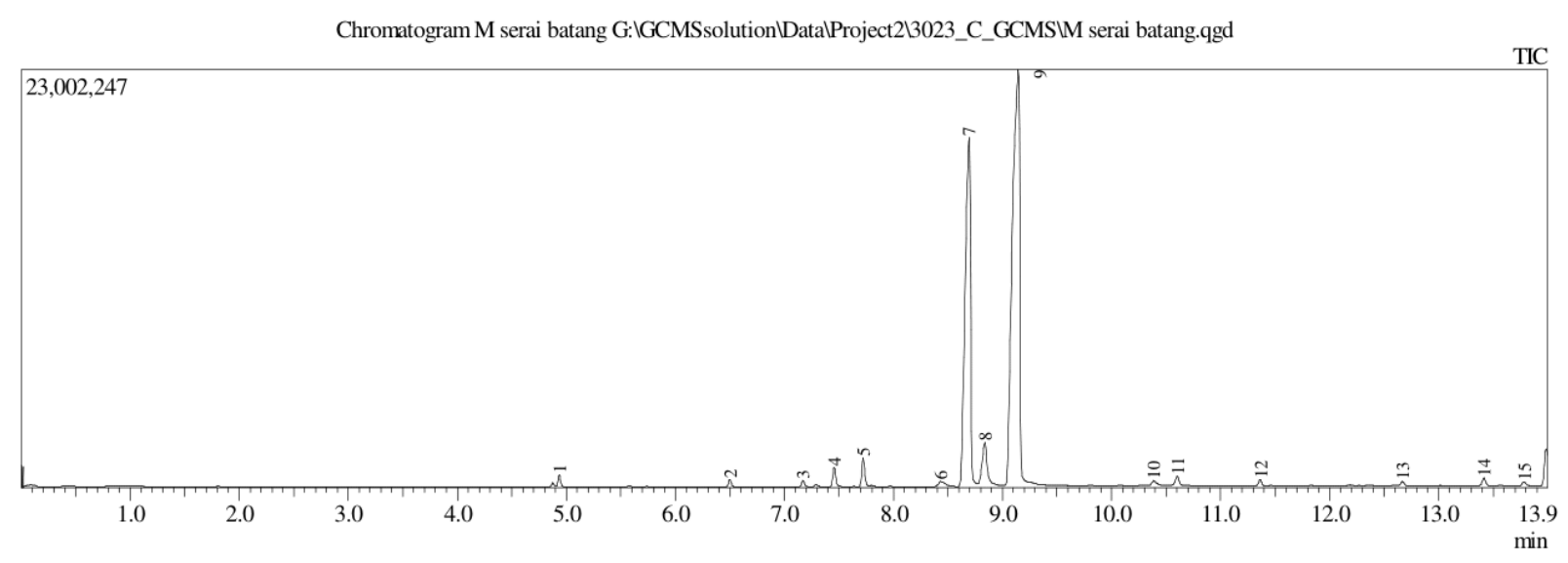

(Gambar 9. Kromatogram dari Minyak Serai (bag. Batang)) 
(Tabel 3. Komponen Senyawa Minyak Serai (bag. Batang))

\begin{tabular}{cccc}
\hline Peak & R. Time [min] & \%Area [\%] & Components \\
\hline 1. & 4,934 & 0,54 & $\beta$-Myrcene \\
2. & 6,500 & 0,38 & Linaloo \\
3. & 7,170 & 0,34 & E-Citral \\
4. & 7,454 & 1,06 & Trans-p-Mentha-1(7) \\
5. & 7,722 & 1,53 & Trans-Caran \\
6. & 8,434 & 0,50 & $\beta$-Citronell \\
7. & 8,694 & 36,62 & Z-Citral \\
8. & 8,838 & 4,07 & Geraniol \\
9. & 9,145 & 54,57 & Citral \\
10. & 10,385 & 0,41 & Phenol \\
11. & 10,602 & 0,57 & Neryl Acetate \\
12. & 11,363 & 0,36 & Trans $(\beta)-$ \\
& & & Caryophyllene \\
13. & 12,666 & 0,22 & Delta-Cadinen \\
14. & 13,416 & 0,51 & Naphthalene \\
15. & 13,781 & 0,32 & $2-$ \\
& & & Naphthalenemethanol
\end{tabular}

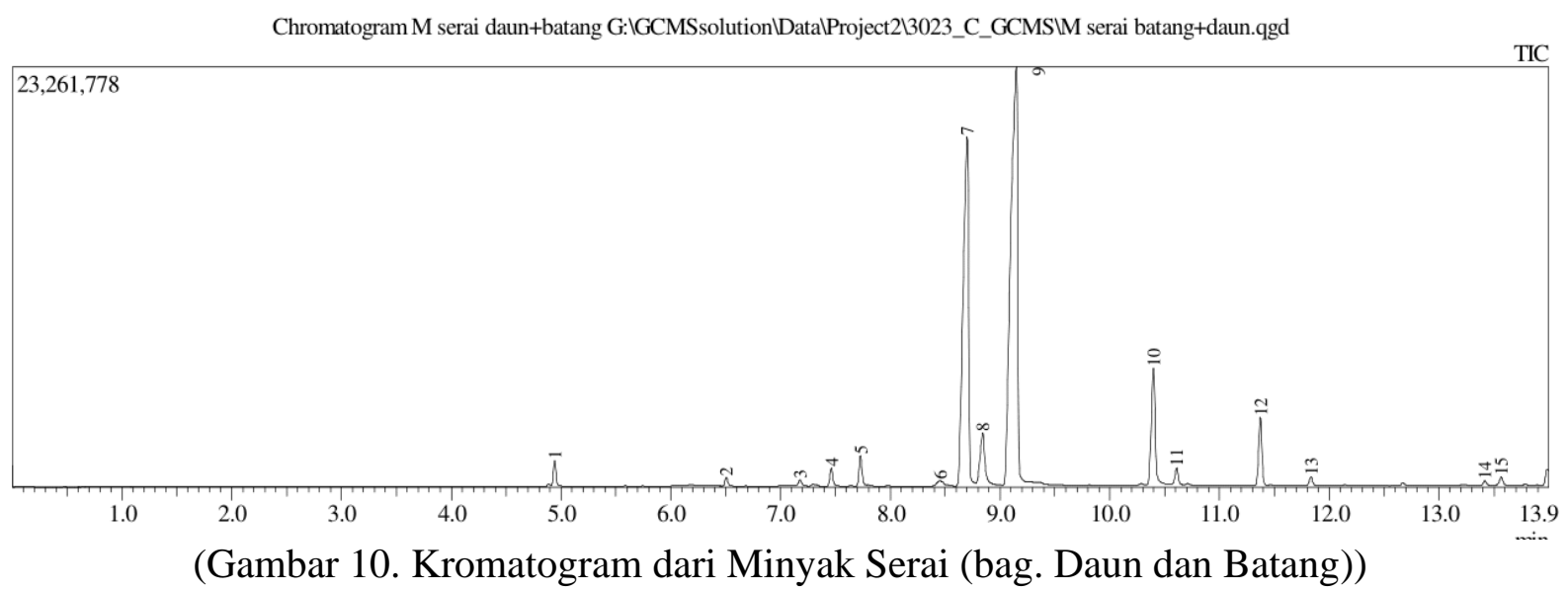


(Tabel 4. Komponen Senyawa Minyak Serai (bag. Daun dan Batang))

\begin{tabular}{cccc}
\hline Peak & R. Time [min] & \%Area [\%] & Components \\
\hline 1. & 4,942 & 1,11 & $\beta$-Myrcene \\
2. & 6,506 & 0,43 & Linaloo \\
3. & 7,176 & 0,28 & E-Citral \\
4. & 7,461 & 0,91 & Trans-p-Mentha-1(7) \\
5. & 7,728 & 1,50 & Trans-Caran \\
6. & 8,457 & 0,44 & Nerol \\
7. & 8,701 & 31,10 & Z-Citral \\
8. & 8,841 & 4,03 & Geraniol \\
9. & 9,148 & 46,62 & Citral \\
10. & 10,397 & 7,51 & Phenol \\
11. & 10,608 & 0,98 & Neryl Acetate \\
12. & 11,372 & 3,79 & Trans $(\beta)-$ \\
& & & Caryophyllene \\
13. & 12,833 & 0,50 & $\alpha$-Humulene \\
14. & 13,418 & 0,27 & Naphthalene \\
15. & 13,566 & 0,53 & (-)-Caryophyllene \\
& & & oxide
\end{tabular}

\section{Hasil Kuisioner}

Hasil kuisioner tentang pengetahuan masyarakat desa Pelutan tentang minyak atsiri ditampilkan pada Tabel 5. Berdasarkan hasil kuisioner tersebut, terlihat bahwa terjadi peningkatan pemahaman, pengetahuan masyarakat tentang minyak atsiri dan peluang bisnis minyak atsiri. Rata-rata $85 \%$ responden mengatakan sudah mengenal minyak atsiri, mengetahui bahwa empon-empon dapat diolah sebagai minyak atsiri, tahu cara mengelola bahan baku menjadi minyak atsiri, mengetahui pentingnya kemasan yang menarik, dan berkeinginan mengembangkan industri rumah tangga atsiri di Desa Pelutan. Masalah yang masih dihadapi adalah pemasaran produk atsiri secara online. Hanya 50\% Responden yang mengetahui cara pemasaran produk secara online, walaupun pelatihan sudah dilakukan.

Berdasarkan hasil kuisioner tersebut dan pengamatan antusias masyarakat Pelutan dalam produksi minyak atsiri, peluang Desa Pelutan sebagai sentra produksi minyak atsiri sangat besar dan menjanjikan. Desa Pelutan dapat mengadopsi Model Techno-industrial Cluster Minyak Atsiri sehingga dapat berkembang sebagai Desa wisata dan sentra produksi minyak atsiri [21].

(Tabel 5. Data Kuesioner Pengetahuan Masyarakat Desa Pelutan tentang Minyak Atsiri)

\begin{tabular}{|c|c|c|c|c|c|c|c|c|}
\hline Ya/Tidak & A & B & C & D & E & F & G & H \\
\hline Ya & 9 & 8 & 8 & 9 & 9 & 9 & 5 & 8 \\
\hline Tidak & 1 & 2 & 2 & 1 & 1 & 1 & 5 & 1 \\
\hline
\end{tabular}

Keterangan:

A. Apakah anda mengetahui yang dimaksud dengan minyak atsiri? 
JAMALI - Volume. 01, Issue. 02, September 2019

B. Apakah anda mengetahui bahwa empon-empon yang dihasilkan di Desa Pelutan dapat menghasilkan minyak atsiri?

C. Apakah anda mengetahui cara mengolah empon-empon menjadi produk olahan minyak atsiri?

D. Apakah anda tertarik untuk mengembangkan empon-empon Desa Pelutan menjadi produk olahan minyak atsiri?

E. Apakah anda dapat melakukkan tata kelola keuangan, sumber daya manusia, dan proses industri dalam mengolah minyak atsiri?

F. Menurut anda apakah kemasan memiliki peran penting dalam penjualan produk?

G. Apakah anda mengetahui cara pemasaran produk secara online?

H. Apakah anda tertarik untuk mengembangkan industri rumah tangga di Desa Pelutan?

\section{KESIMPULAN}

Kegiatan pemberdayaan yang dilaksanakan mendapat dukungan penuh dari Pemerintah dan masyarakat Desa Pelutan. Pengolahan potensi desa berupa empon-empon menjadi produk berbasis minyak atsiri dapat menjadikan Desa Pelutan sebagai sentra industri berbasis minyak atsiri dan meningkatkan perekonomian masyarakat. Dalam pengembangan Desa Pelutan sebagai sentra produksi minyak atsiri dapat mengikuti model Techno-industrial Cluster Minyak Atsiri, sehingga dapat berkembang dengan pesat.

\section{UCAPAN TERIMA KASIH}

Penulis mengucapkan terima kasih kepada Direktorat Riset dan Pengabdian Masyarakat, Direktorat Jenderal Penguatan Riset dan Pengembangan, Kementrian Riset, Teknologi, dan Pendidikan Tinggi atas dana hibah yang diberikan sesuai dengan Perjanjian Penugasan Pelaksanaan Program Pengabdian Masyarakat Nomor: 109/SP2H/PPM/DRPM/2019, tanggal 8 Maret 2019.

\section{REFERENSI}

[1] Anonim. 2019. Profil Desa Pelutan, Kecamatan Gebang, Purworejo. Laporan KKN angkatan 59 Universitas Islam Indonesia. Yogyakarta.

[2] Anonim. 2019. Portal resmi Kabupaten Purworejo, Jawa Tengah. http://purworejokab.go.id/web/komoditas-pangan-\&ampamp-holtikultura.html

[3] Santoso, H.B. 1992. Bertanam dan Penyulingan Serai Wangi. Kanisius, Yogyakarta.

[4] Cook, dkk., 2016. Essential Oils: Isolation, Production and Uses. Encyclopedia of Food and Health. 
[5]Wany, Aakanksha., et al. 2013. Chemical Analysis And Therapeutic Uses Of Citronella Oil From Cymbopogon Winterianus: A Short Review. International Journal of Advanced Research. India.

[6] Han X, Parker TL. Lemongrass (Cymbopogon flexuosus) essential oil demonstrated antiinflammatory effect in pre-inflamed human dermal fibroblasts. Biochim Open. 2017;4:107111. Published 2017 Mar 21. doi:10.1016/j.biopen.2017.03.004

[7] Boukhatem MN, Ferhat MA, Kameli A, Saidi F, Kebir HT. Lemon grass (Cymbopogon citratus) essential oil as a potent anti-inflammatory and antifungal drugs. Libyan $\mathbf{J}$ Med. 2014;9:25431. Published 2014 Sep 19. doi:10.3402/ljm.v9.25431

[8] Tongnuanchan, P etc. 2014. Essential Oils: Extraction, Bioactivities, and Their Uses for Food Preservation. Journal of food science, vol.79. issue 7. Page R1231-R1249

[9] Zhang C, Liu R, He J, Ma Z, Zhang X. Chemical Compositions of Ligusticum chuanxiong Oil and Lemongrass Oil and Their Joint Action against Aphis citricola Van Der Goot (Hemiptera: Aphididae). Molecules. 2016;21(10):1359. Published 2016 Oct 12. doi:10.3390/molecules21101359

[10]Li C.C, Yu H.F, Liu Y.T, Yao H.T. 2018. Effects of lemongrass oil and citral on hepatic drugmetabolizing enzymes, oxidative stress, and acetaminophen toxicity in rats. J Food Drug Anal. 26(1):432-438. doi: 10.1016/j.jfda.2017.01.008.

[11]Yulianti, S dan Suyanti. 2012. Panduan Lengkap Minyak Atsiri. Penebar Swadaya, Jakarta.

[12]Fitri, N., etc. 2017. A Comparative Study of Water-Steam Distillation with Water-Bubble Distillation Techniques to Increase the Quality of Patchouli Essential Oil. Proceeding IOP. 1823, 020123 (2017); doi: 10.1063/1.4978196

[13]Ma'mun dan Nurdjannah, N. 1993. Pengaruh Perajangan dan Lama Pelayuan terhadap Rendemen dan Mutu Minyak Serai Dapur (Cymbopogon citratus Stapf). Balai Penelitian Tanaman Rempah dan Obat. Bul. Litro. Vol VIII. No. 1. Hal: $42-45$.

[14]Rusli, M.S. 2010. Sukses Memproduksi Minyak Atsiri. Agromedia Pustaka, Jakarta.

[15]Botta, Walmince., dkk., 2015. Potensi Senyawa Minyak Sereh Wangi (Citronella Oil) Dari Tumbuhan Cymbopogon Nardus L. Sebagai Agen Antibakteri. Jurnal FT-UMJ. ISSN : 2407 $-1846$

[16]Dikki, dkk., 2016. Karakterisasi Dan Aktivitas Repelen Minyak Atsiri Sereh Wangi (Cymbopogon nardus L), Akar Wangi (Vetiveria zizanoides L.), Nilam (Pogestemon cablin), Cengkeh (Syzgium aromaticum) Asal Kabupaten Garut Terhadap Nyamuk Aedes Aegypti Betina. Jurnal Farmasi. 
JAMALI - Volume. 01, Issue. 02, September 2019

[17]Edward-Jones V, 2013,Alternative Antimicrobial Approaches to Fighting Multidrug-Resistant Infections. In: Fighting Multidrug Resistance With Herbal Extracts, Essential Oils and Their Components. Rai M, Kon K, (Eds.), Amsterdam: Academic Press.

[18]Wany, Aakanksha., et al. 2013. Extraction And Characterization Of Essential Oil Components Based On Geraniol And Citronellol From Java Citronella (Cymbopogon Winteranius Jowitt). Plant Growth Regal. Springer Science \& Business Media Dordrecht.

[19]Falcão, M., Pereira, M.A.A., Fianco, A.L.B. and Torres, Fernando. (2012). Determination of antibacterial activity of vacuum distillation fractions of lemongrass essential oil. Phytochem, 11, 4 .

[20]Guenther. 1990. Minyak Atsiri, Jilid II. Universitas Indonesia Press, Jakarta.

[21] Fitri, N dkk. 2015. Pengembangan Model Techno-industrial Cluster Minyak Atsiri. Jurnal Inovasi dan Kewirausahaan. Vol.4 no.3. 